\title{
VIEWPOINT Periodic corrections to agricultural land values provide opportunity for conservation
}

\author{
Larkin A. Powell
}

$\mathbf{P}$

rivate landowners manage over $75 \%$ of the land in the United States. More than $90 \%$ of each state's area in the Midwest and Great Plains is owned privately (Powell 2012). Thus, the decisions made on private lands may serve as major sources of change in farmed landscapes and ecosystems.

Federal conservation programs, such as the Conservation Reserve Program (CRP), can substantially affect landscapes. In 2013, 2\% of the surface area of Nebraska and $4.5 \%$ of Iowa was protected through enrollment in CRP (USDA 2014a). However, natural resource planners who work to conserve soil, water, and wildlife on private lands are faced with the complex task of finding willing landowners to enroll in the portfolio of federal conservation programs. A variety of factors motivate landowner decisions (Quinn and Burbach 2008), but economic considerations are usually a clear driver (Cary and Wilkinson 1997).

High prices paid for commodities have recently competed with conservation interests (Powell 2012). For example, acres enrolled in CRP declined by $18 \%$ during 2007 to 2013 in the United States. Four midwestern states-Iowa, Illinois, Minnesota, and Missouri-saw an average decline of acres in CRP of $12 \%$. Four states in the northern Great PlainsKansas, Nebraska, South Dakota, and North Dakota - had an average decline of acres in CRP of 24\% during 2007 to 2013 (USDA 2014b; figure 1).

Such trends have caused conservation scientists to pause and reflect, perhaps fretfully, on the future of conservation on private lands (Ciuzio et al. 2013; Powell 2012). However, conservation has been successful in the past, and the economic

Larkin A. Powell is a professor in the School of Natural Resources and director of the Great Plains Cooperative Ecosystem Studies Unit at the University of Nebraska-Lincoln, Lincoln, Nebraska.

\section{Figure 1}

Loss of warm-season dominated grasslands enrolled in the Conservation Reserve Program on a farm in northeastern South Dakota; photos from (a) July 2013 at end of previous 10-year contract, and (b) October 2013 after contract was allowed to expire. Photos by Scott Groepper.

(a)

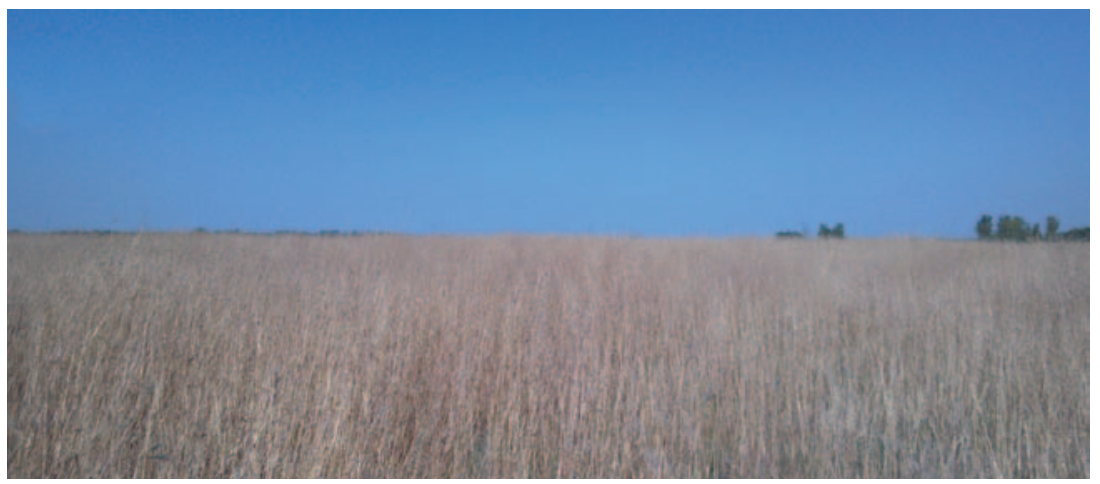

(b)

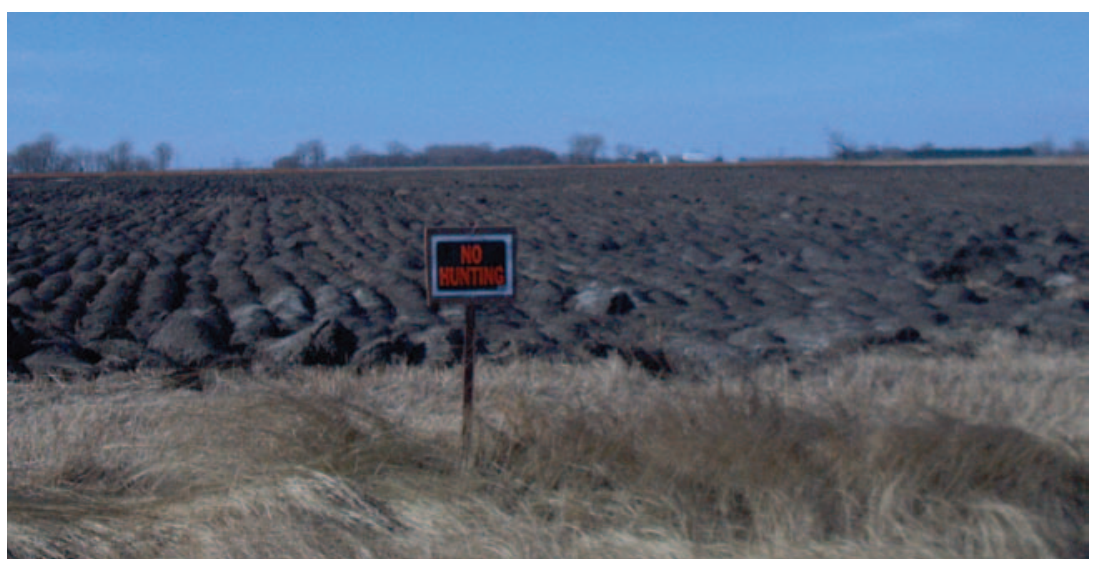

landscape of agriculture is one of constant change. Rather than retreating from the front lines of conservation in dismay, I suggest that economic cues give reason for conservationists to anticipate an impending opportunity to create real and lasting change on agricultural landscapes through new directions to farm policy.

\section{CONSERVATION AND LAND VALUES: A LOOK BACK}

The history of federal conservation programs in the United States is a lesson in policy, politics, and crisis management. Early programs used erosion control as a vehicle to get funds to cash-strapped farmers during the Great Depression. Later programs attempted to control commodity price and supply. Recent farm bills have included components to reduce risk while expanding conservation to the broad ecosystem, including wildlife (Cain and Lovejoy 2004). Modern assessments and knowledge of the function of agroecosystems have given conservation planners visions of what conservation programs could provide to landscapes. Although the potential for real change is present, incentives that fund subsidy programs are garnered through taxpayer supports; lack of funds and the political climate in Congress have caused lengthy delays in the delivery of the most recent farm bills. However, such opposition has not been the status 
quo. What causes variation in the weight of political opposition to farm subsidies?

The farm economy, including valuation of land, is driven by commodity prices-a dance of supply and demand affects what farmers receive for their products and what they are willing to pay for inputs. Commodity prices do not increase in linear fashion (Powell 2012). For example, corn (Zea mays L.) prices in Nebraska topped US $\$ 39 \mathrm{t}^{-1}$ (US $\left.\$ 1 \mathrm{bu}^{-1}\right)$ because of export demand during World War I, but fell back to a five-year average price of US $\$ 20 \mathrm{t}^{-1}$ to US $\$ 30 \mathrm{t}^{-1}$ (US\$0.50 bu ${ }^{-1}$ to US $\$ 0.75 \mathrm{bu}^{-1}$ ) during the 1920 s and 1930s. A surge in export demand caused by World War II raised the price to a new level-back to US $\$ 39 \mathrm{t}^{-1}$, where it generally remained for 25 years. New export markets in the 1970s again raised the price of corn to US $\$ 98 \mathrm{t}^{-1}$ (US\$2.50 $\mathrm{bu}^{-1}$ ) for the next 30 years, when demand caused by ethanol markets brought prices to a new level一over US $\$ 157 \mathrm{t}^{-1}\left(\mathrm{US} \$ 4 \mathrm{bu}^{-1}\right)$.

Higher commodity prices initially result in larger profits for farmers. And, profits bring the potential for capital investments in more land, machinery, and other ventures. The history of US agriculture can be described as "boom and bust" (Henderson et al. 2011), often caused by accumulation of debt by farmers during boom times when profits are high and interest rates are low. Profits fall when the cause of temporary booms is removed, yet the debt remains, and a bust follows.

Land values follow commodity prices, and land values have similar nonlinear price trends. Annual records of average land values (including buildings) for states in the United States are available from 1910 to present day (USDA NASS 2014). A 10-year change in values for land values was calculated for eight representative states (Midwest: Illinois, Iowa, Minnesota, and Missouri; Northern Great Plains: Kansas, Nebraska, South Dakota, and North Dakota; figure 2). Every state in the assessment showed similar, synchronized patterns of cyclical land values-booms and busts. Four booms have occurred since 1910 - in 1920, early 1950s, early 1980 s, and in the early 2010 s. The interval between the peaks of each boom was almost exactly 30 years. Busts, as described by changes in land values, occurred during 1920s and 1930s, the 1950s, and the 1980s, and busts precipitously followed peak booms. If history is our guide, the current peak in the 2010s suggests that farm land value is slated for a correction in the near future. However, the impending correction may be less of a bust than the 1930s and 1980s because farmers have apparently not yet extended themselves with debt (Henderson et al. 2011).

\section{CRISIS: OPPORTUNITY FOR CONSERVATION}

How can the history of land values be used for conservation planning? If we overlay the cycle of booms and busts in American agriculture with a review of conservation programs, we see that busts are times for innovation and movement in conservation. History shows that political will and innovation come together during times of economic crisis to shape the future of conservation.

The Great Depression brought the first efforts of the federal government to be involved in supporting agriculture. In fact, the federal government became involved in conservation because the Supreme Court ruled that the 1933 Agriculture Adjustment Act, which featured direct payments to farmers who reduced output of certain commodities for price relief, was not constitutional. The Court reasoned that public money was being used to support individuals and was not clearly for the good of the public. The clever response to this legal ruling was the creation of the Soil Conservation Act of 1935 that brought payments to farmers who used conservation practices. Conservation of soil and water was in the public interest, so the new type of payments could not be challenged in a fashion similar to the successful attempt to dislodge the Agriculture Adjustment Act. Thus, federal conservation programs were established largely as a legal maneuver. The program featured the development of the Soil Conservation Service (later, Natural Resources Conservation Service [NRCS]), and the Soil Conservation and Domestic Allotment Act of 1936 fol- lowed suit. Farmers were paid to replace soil-depleting crops, including corn and wheat (Triticum aestivum L.), with soilconserving crops such as legumes, grasses, or cover crops (Cain and Lovejoy 2004). The goals were to support farmers and change the type of crops planted to save soils. Congress' innovation was to use conservation goals as the method of delivery of monetary support to farmers.

After World War II, farmers were faced with a surplus of crops as demand fell from wartime levels (Henderson et al.2011). The post-war recession of the 1950s marked the next period of land value correction (figure 1). At the depth of the recession, a new type of conservation program emerged: the Agriculture Act of 1956, commonly referred to as the "Soil Bank" program. Twelve million ha (29 million ac) were removed from production in return for government rental payments under a 10-year contract. Programs targeted soil, water, forest, and wildlife conservation (Cain and Lovejoy 2004). The goal, and the new innovation, was to reduce supplies of commodities by removing land from production. Conservation, as before, provided the legal vehicle for federal payments to individual farmers.

The Farm Crisis of the 1980s was a much more severe correction than the recession of the 1950s (figure 2). The first of a string of appropriately named "farm bills" appeared in 1985. The Conservation Reserve Program was created. The timing of this economic downturn provided the innovation, as the 1970s had been a decade of public attention to the needs of the environment. Previous conservation efforts had supported soil and water conservation, in large part, so that agricultural production could be sustained. The 1985 Farm Bill went beyond concern for public food supply to introduce new goals: improve water, soil, and air quality for the public good. The role of the farm landscape in wildlife conservation was also cemented in the language of the bill. The innovation found in this bill was to lump environmental goals and efforts into agricultural legislation (Cain and Lovejoy 2004). 


\section{Figure 2}

Ten-year changes in land values (including buildings) for eight representative states in the Midwest ([a] Illinois, [b] lowa, [c] Minnesota, and [d] Missouri) and the Northern Great Plains of the United States ([e] Kansas, [f] Nebraska, [g] North Dakota, and [h] South Dakota). Changes are calculated as current land values divided by land values 10 years previous; change in value is shown as a percentage of the previous land value. For comparison, a dotted line is shown at $100 \%$ to represent no change.

(a)

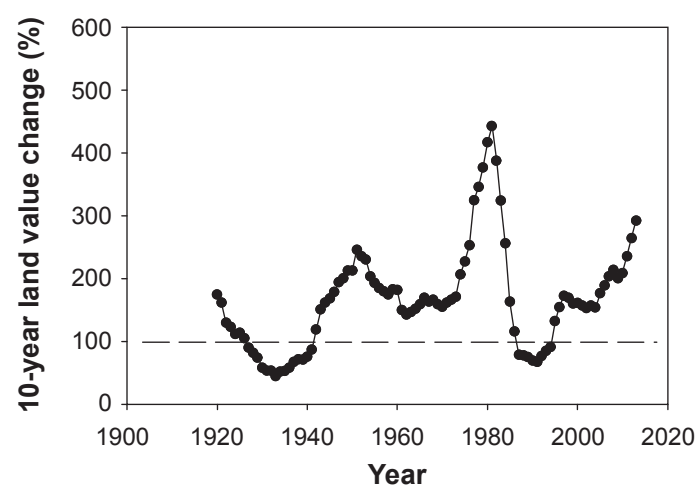

(c)

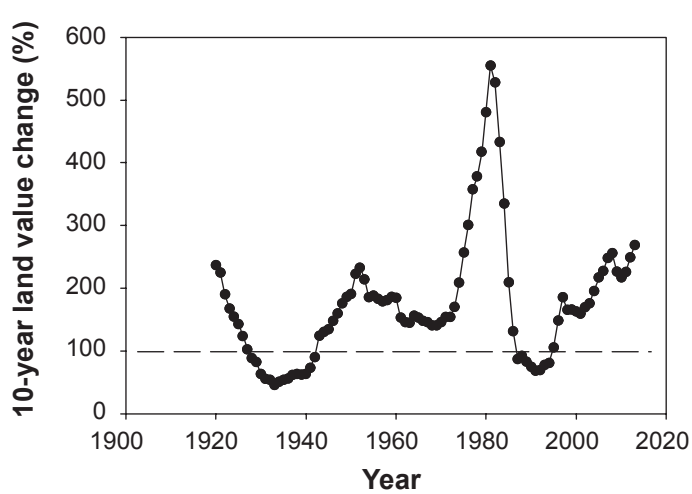

(e)

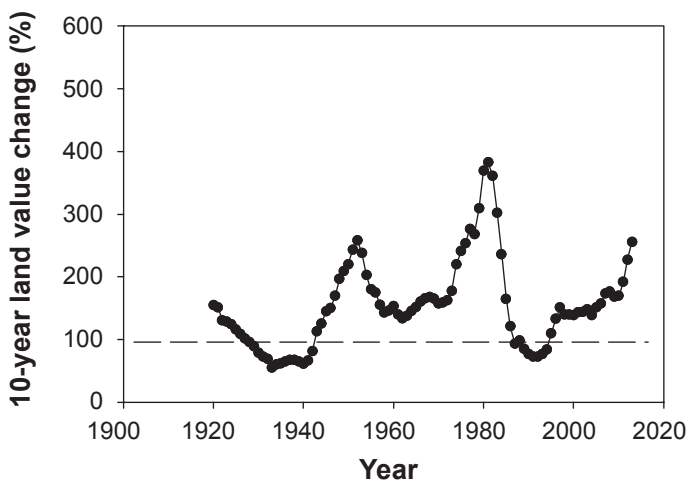

(g)

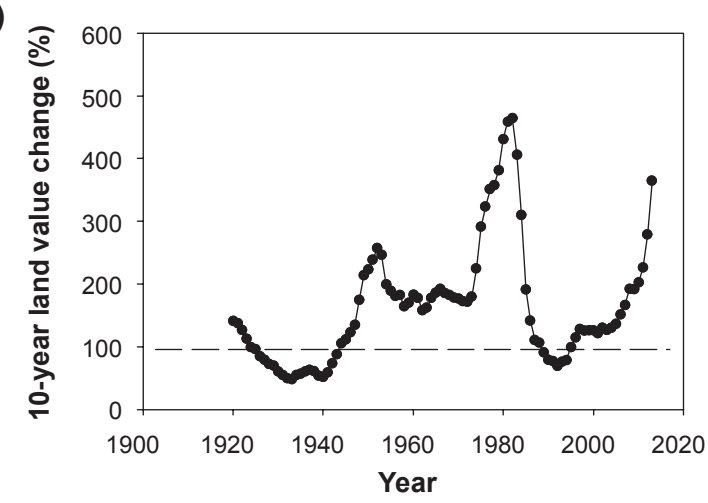

(b)

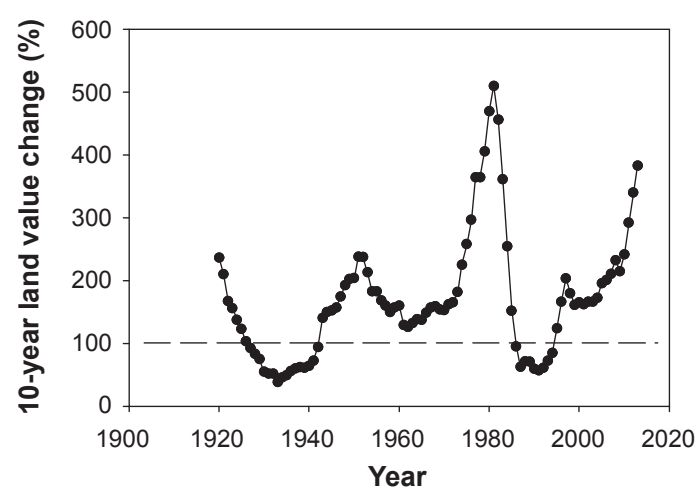

(d)

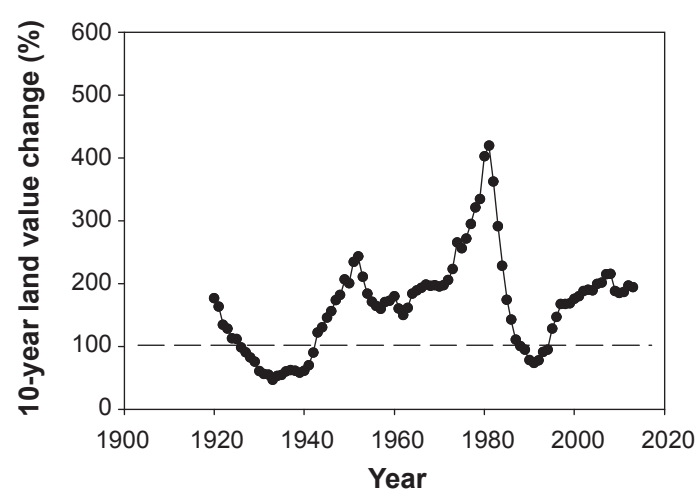

(f)

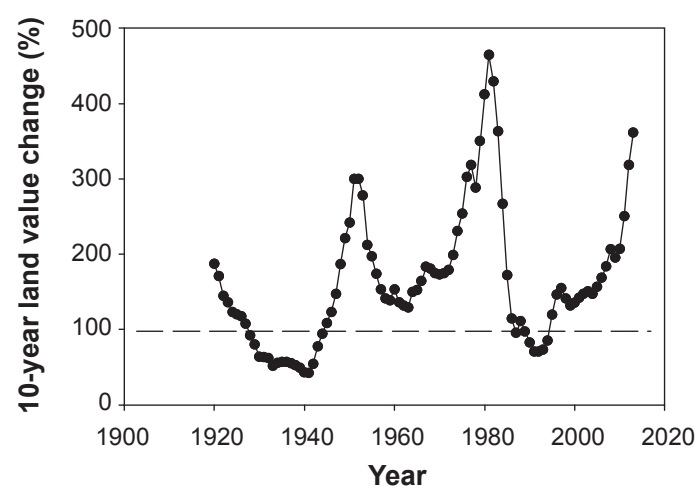

(h)

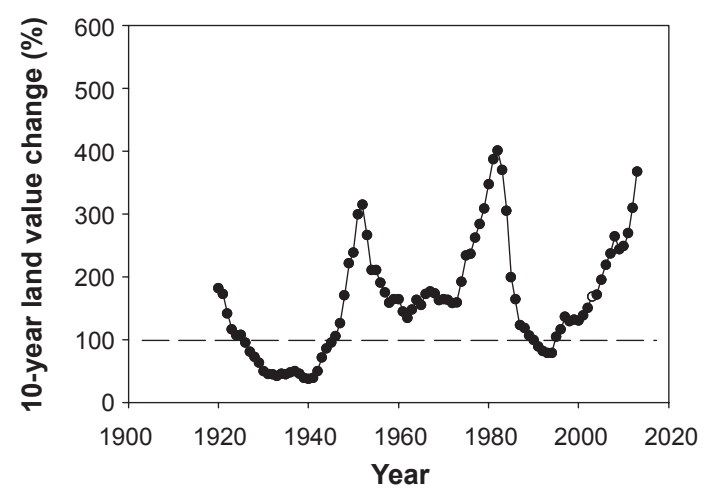


Approximately 20 pieces of legislation could be labeled as farm bills since the 1930s. The innovation and change in the type of conservation programs delivered in federal agricultural legislation, however, occurred during three critical times of economic crisis on the American farm. At each juncture, the direction of conservation efforts was reshaped and strengthened.

\section{THE FUTURE}

What will be the next innovation in conservation (figure 3)? Surely, the eventual product will be shaped by the existent political environment, in which tax-supported legislation is highly scrutinized. The 2014 Food, Farms, and Jobs Bill may give some hints at emerging priorities for conservation that could be enhanced through innovative steps.

Corporate Partnerships. Partnerships are emphasized in current legislation in the form of the Regional Conservation Partnership Program. Partners, which can include universities, nonprofits, district and tribal governments, cities and counties, state governments, and other groups, may apply for the opportunity to co-invest with the NRCS to implement conservation through several farm bill programs. Of course, these partnerships extend federal taxpayer funds (USDA 2014a). As an example, a partnership that includes Ducks Unlimited and local soil and water conservation districts has worked with the NRCS in southwest Louisiana to promote wildlife habitat and water use efficiency on 3,237 ha $(8,000 \mathrm{ac})$ of private lands (NRCS 2014a). Public/private partnerships have been goals of federal agencies for the past few decades, and this trend should be expected to continue.

An innovation in partnerships could be to directly target agribusiness, which is a beneficiary of the farm bill legislation and is often a driver of trends that reduce wildlife habitat (Czech 2000) and threaten water quality (Pucket 1995). Could agribusiness provide directed investments in the working landscapes of America through corporate/ private partnerships? Food processing companies benefit handsomely from farm bills and lobby Congress extensively. Could they partner with farmers on landscapes to contribute to conservation?

\section{Figure 3}

The future of farm policy will depend on the farm economy. Farmers and agribusiness have vested interest in new farm policy programs. Wildlife and aquatic ecosystems may feature prominently in the priorities of future farm bills.

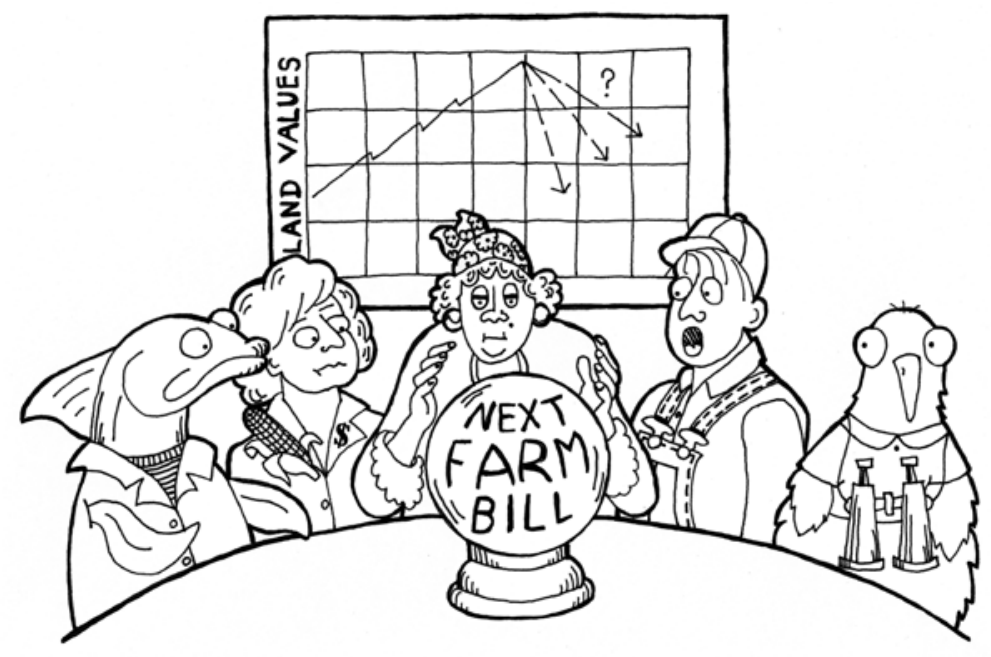

So....what do you see?

A model for contributions of industry to conservation can be found in the federal aid in the Wildlife Restoration Act of 1937, also known as the PittmanRobertson Act.The legislation provided an $11 \%$ federal excise tax on hunting equipment that was used to promote habitat restoration. The firearm and ammunition industries supported the new tax, but they had a vested interest: game animals were disappearing from landscapes because of overhunting, and gun sales were declining. Public sentiment was also in favor of wildlife conservation. Thus, a tax that would result in larger populations of wildlife had clear benefits to future profits for gun makers and ammunition suppliers (Buck 1996). Are similar benefits present for agribusiness today? Certainly, agribusiness would not lose profits if all wildlife were to disappear from the landscape; in fact, profits might increase with more intense production. However, water and soil form the foundation that supports agribusiness; without these resources, the industry agribusiness ceases to exist. Innovative schemes to support soil and water conservation might serve as incentive for agribusiness to co-invest back in the landscapes that drive the industry.

Private Investment. Conservation can be supported in a sustainable fashion by landowners who invest in nature-based entrepreneur activities, such as private nature reserves, lodges, campgrounds, or lakes for fishing (Powell 2012). Private investment has potential to result in profitable ventures. In 2011, 90.1 million participants in the United States spent US $\$ 144.7$ billion on wildlife-related recreation, such as hunting, fishing, and wildlife watching (US Fish and Wildlife Service 2011).The 2014 Farm Bill includes support for rural development and conservation easements, which emphasizes goals to support rural economies and protect land for periods longer than the 10-year contracts used for CRP (USDA 2014a). Future legislation could also target ruralbased businesses that rely on grasslands, forests, or wetlands. By cost-sharing startup of nature-based businesses, taxpayer funds would be matched by private citizens who have a stake in keeping the land under protection for years to come.

Landowner Collaborations. A recent innovation in conservation is a focus on the benefits of leveraging efforts of groups of landowners in critical landscapes. Such efforts are often labeled as "conservancies," "land trusts," or "watershed projects" (Powell 2012; Schutz 2010). Current CRP scoring systems provide additional points for applicants 
with lands in priority watersheds (usually with water or soil quality issues). A possibility for the future would be to give landowners additional points if they work with conservation planners to develop a conservation plan for their watershed. Priority could also be given to landowners who apply as coordinated groups.

Environmental Compliance. The 2014 Farm Bill links crop insurance subsidy payments to environmental compliance for farms who receive benefits. The current political climate would suggest that scrutiny of taxpayer funds will result in continued insistence on multiple benefits for taxpayer investment in agriculture. A time of heightened political will may encourage implementation of a new model for risk support.

Focus on Environmentally Friendly Production. World population growth, and its associated food needs, may eventually provide political opposition to conservation programs, such as CRP, that remove land from production. Of course, CRP has been the flagship of conservation efforts for the past four decades. Innovation in conservation should account for the demand for food. In such a political environment, how can we work to support landscapes that have refuges for wildlife and filter strips for water quality and soil conservation? Can priority be given to strip farming, cover crops, and other innovative methods to single- or double-crop lands without threatening environmental quality and standard of living for those who live in rural landscapes? Certainly, a reduction in set-aside land would have consequences to conservation for water, soils, and wildlife. The challenge to provide meaningful conservation on production lands may well provide a stimulus for innovation.

The current Conservation Stewardship Program (CSP) may provide a hint at the type of subsidies that could be used in the future on working lands. Creative, environmental design may find new ways to use grasslands, forests, and wetlands to contribute to farm income while protecting soil, water, air, and wildlife. Currently, the CSP provides results-based payments to landowners who initiate conservation improvements to their property and who develop crop rotations to save resources
(NRCS 2014b). For example, crop farmers may receive payment if their properties have grass or woody buffer areas that intercept field runoff and if they provide wildlife habitat on their farm. Innovations in this area could include the inclusion of specific, multibenefit options for habitat improvement, such as in-field habitat provided by linear, grassy "beetle banks" in the United Kingdom. These grass strips provide wildlife habitat, reduce soil erosion, and reduce the need for insecticide through support of predatory insects and spiders (MacLeod et al. 2004).

Water Quantity. Food crops do not grow without water, and irrigation has provided the mechanism to expand crop production in dry states. However, many western rivers are predicted to fail to meet their current allocated needs under climate change scenarios (Barnett et al 2004). Water quantity issues may indeed be the elephant in the room, with respect to the needs for innovation in conservation programs. Will we see a reemergence of themes of post-Dust Bowl conservation programs with emphasis on subsidizing the switch to water-conserving crops and practices rather than soil-friendly crops? Can crop scientists develop modern, highly productive crop systems that conserve water (Nielsen et al. 2005)? The current CSP provides support for introduction of more efficient irrigation systems and water-conserving crop rotations. It seems justified that water quantity should join water quality as a top priority for conservation in the near future.

Niels Bohr, a Nobel laureate in physics, once commented, "Prediction is very difficult, especially when it's about the future." Certainly, it is foolhardy to make exact predictions about the future of the farm economy. Heightened export demands could create a soft landing for the impending correction in land values. Alternatively, farmers might continue to invest in capital improvements beyond the cash they have at hand, which could leave them overextended when land values correct.

We know that previous booms in agriculture quickly faded (Henderson et al. 2011). We also know that land values in 2013 were at record levels, relative to the values of 10 years previous. Additionally, many commodity values have dropped significantly in 2014. A correction is coming (Henderson et al. 2011). Most importantly, history shows that an opportunity may soon present itself to allow the creation and implementation of innovative conservation programs during period that follows the correction in land values. Conservation planners should be ready.

\section{ACKNOWLEDGEMENTS}

Dee Ebbeka, University of Nebraska-Lincoln, Lincoln, Nebraska, created figure 3 as original artwork. I am grateful to Mark Pegg, University of Nebraska-Lincoln, Lincoln, Nebraska, for a review that improved this manuscript. My efforts were supported by Hatch Act funds through the University of Nebraska Agricultural Research Division, Lincoln, Nebraska.

\section{REFERENCES}

Barnett, T., R. Malone, W. Pennell, D. Stammer, B. Semtner, and W. Washington. 2004. The effects of climate change on water resources in the west: introduction and overview. Climate Change 62:1-11.

Buck, S.J. 1996. Walking like a duck: The Wildlife Diversity Funding Initiative. Voices from the Commons: the Sixth Biennial Conference of the International Association for the Study of Common Property, June 5-8, 1996. http://dlc. dlib.indiana.edu/dlc/handle/10535/827.

Cain, Z., and S. Lovejoy. 2004. History and Outlook for Farm Bill Conservation Programs. Choices. 2004, $4^{\text {th }}$ Quarter:37-42.

Cary, J.W., and R.L. Wilkinson. 1997. Perceived profitability and farmers' conservation behavior. Journal of Agricultural Economics 48:13-21.

Ciuzio, E., W.L. Hohman, B. Martin, M.D. Smith, S. Stephens, A.M. Strong, and T. Vercauteren. 2013. Opportunities and challenges to implementing bird conservation on private lands. Wildlife Society Bulletin 37:267-277.

Czech, B. 2000. Economic growth as the limiting factor for wildlife conservation. Wildlife Society Bulletin 28:4-14.

Henderson, J., B. Glay, and M. Boehlje. 2011. Agriculture's boom-bust cycles: Is this time different? Economic Review, Federal Reserve Bank of Kansas City. Fourth Quarter 2011:83-105.

MacLeod, A., S.D. Wratten, N.W. Sotherton, and M.B. Thomas. 2004. 'Beetle banks' as refuges for beneficial arthropods in farmland: Long-term changes in predator communities and habitat. Agricultural and Forest Entomology 6:147-154. 
Nielsen, D.C., P.W. Unger, and P.R. Miller. 2005. Efficient water use in dryland cropping systems in the Great Plains. Journal of Agronomy 97:364-372.

Powell, L.A. 2012. Common-interest community agreements on private lands provide opportunity and scale for wildlife management. Animal Biodiversity and Conservation 35:295-306.

Pucket, L.J. 1995. Identifying the major sources of nutrient water pollution. Environmental Science \& Technology 29:408A-414A.

Quinn, C.E., and M.E. Burbach. 2008. Personal characteristics preceding pro-environmental behaviors that improve surface water quality. Great Plains Research 18:103-14.

Schutz,A.B., 2010. Grassland governance and commoninterest communities. Sustainability 2:2320-2348.

USDA. 2014a. 2014 Farm Bill Highlights. http:// www.usda.gov/documents/usda-2014-farm-billhighlights.pdf.
USDA. 2014b. Changes in CRP Acreage from 2007 to October 2013 by State. http://www.fsa.usda. gov/Internet/FSA_File/enrolledstate13.xls.

USDA NASS (National Agricultural Statistics Service). 2014. Data and Statistics. http://www. nass.usda.gov/Data_and_Statistics/.

USDA NRCS (Natural Resources Conservation Service). 2014a. RCPP Partner Testimonials. http://www.nrcs.usda.gov/wps/portal/nrcs/ detail/national/home/?cid=stelprdb1253919.

USDA NRCS. 2014b. Conservation Stewardship Program. http://www.nrcs.usda.gov/wps/por$\mathrm{tal} / \mathrm{nrcs} / \mathrm{main} / \mathrm{national} /$ programs/financial/ $\mathrm{csp} /$.

US Fish and Wildlife Service. 2011. 2011 National survey of fishing, hunting, and wildlife-associated recreation: National overview. http:// digitalmedia.fws.gov/cdm/ref/collection/ document/id/859. 